\title{
Limnological Studies of Pedda Cheruvu Lake in Rajgopalpet, Siddipet District, Telangana State
}

\author{
${ }^{1}$ D. Srinivas*, ${ }^{*}$ Dr. K. Shailaja \\ Department of Botany, University College of Science, Osmania University, Hyderabad, India
}

\section{Article Info \\ Volume 8, Issue 1 \\ Page Number: 212-222}

Publication Issue :

January-February-2021

\section{Article History}

Accepted : 08 Feb 2021

Published : 18 Feb 2021

\section{ABSTRACT}

Pure water is the world's first and foremost medicine and lakes are inland water bodies of water. Limnological studies of peddacheruvu Lake, Rajgopalpet, Siddipet district, Telangana state was carried out was over period of two years. The physico-chemical characteristics were studied and analyzed during the period of one year. Seasonal variations at three different stations of the lake were observed. Sewage drains, clothes washing, bathing of animals, agro-waste with pesticides residue and rituals waste drains into the lake may result into the change in physico-chemical characteristics of lake water. Some parameters like $\mathrm{pH}$, temperature, Dissolved oxygen, Hardness, Nitrate, silicates and Phosphates etc. studied throughout year.

Keywords : Limnological study, Physico-chemical, variations, peddacheruvu lake.

\section{INTRODUCTION}

Water is known to contain many chemical elements. The interaction of both the physical and chemical properties of water plays a significant role in the composition, distribution and abundance of aquatic ecosystem. Apart from this, it also gives an insight into the relationships between the organism and their environment and can be used in determining water quality, and productivity of the lake. The physicochemical study could also help in understanding the structure and function of a particular water body in relation its habitants. The proper balance of physical, chemical and biological properties of water in lake is an essential ingredient for successful production of aquatic resources.
Water is one of the important sources, to sustain life and has long been suspected of being the source of much human illness. Source of surface water and ground water have become increasingly contaminated due to increased industrial and agricultural activity. The public desires water that is low in hardness total solids, non-corrosive and non-scale-forming.

A fascinating thing about lakes is that they provide their own variety. The task of limnologist is to measure and interpret this variation whether it concerns physical, chemical, biological phenomena, altitude, geology of the catchments area and the depth of water. Increased use of lakes and reservoirs for recreation, fisheries, water storage for irrigation and 
electric power generation purpose as well as for urban shoreline development, has emphasized the need for intensive water quality studies and management. The physical and chemical limnology of a lake is characterized by hydrological impact, autogenic nutrient dynamic and biological aspects. These factors combine with each other determine the water quality and consequently community of the lake.

Rajgopalpet is a village in Nangunoor mandal, siddipet district in Indian state of Telangana. It is the biggest town in Siddipet district and is located in siddipet to Warangal route. Rajgopalpet is located at Latitude 18009'60"38N, Longitude 78093'73”93E. It has an average elevation of 675 meters (2215feet) above the mean sea level. The village of Rajgopalpet climate was once fairly equitable with maximum temperature $43^{\circ} \mathrm{C}$ and minimum temperature $12^{\circ} \mathrm{C}$, avg. Annual temperature $30^{\circ} \mathrm{C}$, avg. summer temperature $43^{\circ} \mathrm{C}$, and avg. winter is $16^{\circ} \mathrm{C}$.

\section{METHODS AND MATERIAL}

The samples for physico-chemical analysis were collected from peddacheruvu lake, Rajgopalpet, in a period of one year. Separate samples were collected to estimate dissolved oxygen in $250 \mathrm{ml}$ BOD bottles and dissolved oxygen was fixed in the field by adding Wrinkler's reagent immediately after sample collection. The temperature and $\mathrm{pH}$ were measured with the help of thermometer and digital $\mathrm{pH}$ meter at collection site only. The physico-chemical characteristics of the lake water like dissolved oxygen, Total alkalinity, Hardness, silicates, Nitrates and Phosphates were determined in every month according to standard procedure from APHA (2005), Trivedi and Goel (1986).

\section{RESULTS AND DISCUSSION}

Temperature: Water has unique thermal property which combines to minimize temperature changes. It affects on biochemical reactions, population fluctuation of water body as well as physical and chemical characteristics of water. During the present investigation the surface water temperature of lake showed considerable fluctuation. The temperature varies between a December minimum of $22.0^{\circ} \mathrm{C}$ to a June maximum $25.9^{\circ} \mathrm{C}$. The pattern of variation in water temperature was being the lowest in January.

pH:

$\mathrm{pH}$ of surface water ranges between 7.8 to 8.2 and indicated alkaline nature of the water. $\mathrm{pH}$ concentrations was altered with seasons (Ruth et.al., 2013).

\section{Carbonates:}

The occurrence of carbonates in a water body is of immense relevance so much so that most of the physico chemical parameters have a direct bearing with it. In fact it is the prime contributor for maintaining $\mathrm{pH}$ of a water body and ends its role is of vital importance (Hegde et.al. 2005). The highest amount of carbonates found to be $51.92 \mathrm{mg} / \mathrm{l}$ in May and the lowest value was recorded as $25.54 \mathrm{mg} / \mathrm{l}$ in June.

\section{Bicarbonates:}

The greater amount of bicarbonates were identified as $240.64 \mathrm{mg} / \mathrm{l}$ in August due to the accumulation of organic matter produced by decomposition of vegetation and lowest value is $120.34 \mathrm{mg} / \mathrm{l}$ in October due to the inflow of freshwater and dissolution of calcium carbonate ions in the water. 


\section{Dissolved Oxygen (D.O.):}

Oxygen distribution is key criterion as it is the direct need of most of the organism present in the environment. It also affects the solubility and availability of many nutrients and therefore the productivity of aquatic ecosystem. The dissolved oxygen varied in the range of 8.2 to $11.4 \mathrm{mg} / \mathrm{l}$ of observations with an average of $9.77 \mathrm{mg} / \mathrm{l}$. The fluctuation in dissolved oxygen level remained marginal during the period of present investigations.

During summer lowest values of dissolved oxygen may be due to high temperature and low solubility of oxygen in water consequently affecting the BOD. Further, the dissolved oxygen content of water was low in summer because of its enhanced utilization by microorganisms in the decomposition of organic matter (Naik et.al., 2012).

\section{Biochemical Oxygen Demand (BOD):}

In the present work, during the period of investigation, BOD values ranged from $4 \mathrm{mg} / \mathrm{l}$ to 10 $\mathrm{mg} / \mathrm{l}$ in the Peddacheruvu lake. BOD is the major criterion used in stream pollution control where organic loading must be restricted to maintain desired dissolved oxygen. In unpolluted water BOD is lower while it is high in polluted water.

\section{Total Hardness:}

Total hardness ranged between $260.0 \mathrm{mg} / 1$ maximum and a minimum value $146.0 \mathrm{mg} / \mathrm{l}$. was during February. The total hardness values varies widely suggested that the concentration of total hardness might be increased due to input of domestic and other sewage water in the lake. According to Jhingran (1991) soft water lakes are generally poorer in regard to their aquatic fauna and flora and usually contain less living matter per unit area than hard water lakes. Although the total mass of organisms is greater in hard water lakes while medium lakes hold a greater variety of living organisms.

\section{Calcium:}

Calcium is an important nutrient for aquatic organism and it is commonly present in all water bodies (Ansari and Prakash, 2000). The maximum quantity of calcium was recorded in December as $53.96 \mathrm{mg} / \mathrm{l}$ and minimum $36.24 \mathrm{mg} / \mathrm{l}$ amount was determined during February.

\section{Magnesium:}

Magnesium is essential for chlorophyll bearing plant for photosynthesis and act as a limiting factor for the growth of phytoplankton. The highest estimated value of magnesium was $40.22 \mathrm{mg} / \mathrm{l}$ in the month of September and the lowest value was $22.78 \mathrm{mg} / \mathrm{l}$ found in August. Lowering of magnesium level minimizes the phytoplankton population (Govindan and Devika., 1991).

\section{Total Dissolved Solids (TDS):}

The water always contains some dissolved solids in natural condition. The solids remaining in water after filtration are called total dissolved solids. They may be organic or inorganic but precisely, the dissolved solids are composed mainly of carbonates, bicarbonates, chlorides, sulphates, calcium, phosphate and iron (Trivedy, 1986). The greater TDS value for peddacheruvu lake water was estimated to be 435 $\mathrm{mg} / \mathrm{l}$ in the month of April and lower was $310 \mathrm{mg} / \mathrm{l}$ in the month of August.

\section{Chlorides:}

The estimated highest concentration of chloride was $196.98 \mathrm{mg} / \mathrm{l}$ in June. The higher concentration of chloride is considered to be an indicator of higher pollution of due to higher organic waste of animal origin (Ramakrishna et.al.,2005). Due to dilution of lake water with rain water the concentration of chlorides decreases and found $126.25 \mathrm{mg} / \mathrm{l}$ in January. 


\section{Sulphates:}

Sulphates are found in all natural water, especially those with high salt content. Besides industrial pollution and domestic sewage and biological oxidations of reduced sulphur species also add to sulphate content. The highest amount of sulphates was $38 \mathrm{mg} / \mathrm{l}$ during the month of May and lowest was $22 \mathrm{mg} / \mathrm{l}$ in the September month during the period of investigation.

\section{Phosphates:}

Phosphorus is an essential nutrient for primary producer; hence act as one of the limiting factors in the process of eutrophication and lakes can be aesthetically classified into good, fair and bad on the basis of \% phosphates loading. In natural water, phosphorus is present in very small quantities. The main supply of phosphorus only in natural water is from the withering of phosphorus bearing rocks and leaching of the soils of the catchment area by rain. Generally excess of this nutrient through untreated domestic sewage and agricultural runoff lack of phosphorus content of more than $0.20 \mathrm{mg} / \mathrm{l}$ are likely to be quite productive. The phosphate-phosphorus was recorded in the range of 0.38 to $0.98 \mathrm{mg} / \mathrm{l}$ of observations.

\section{Nitrates:}

It is well known fact that the role of the nitrates in biological productivity of aquatic ecosystem. In an aquatic environment, nitrogen is present in combined forms of ammonia, nitrite, nitrate, urea and dissolved organic compounds nitrate ranged between 0.58 to $1.14 \mathrm{mg} / \mathrm{l}$. The marked increase in the nitrates level was observed during months of June probably due to decomposition of macrophytes.

\section{Nitrites:}

In the fresh water nitrites are usually in low quantities compare to other nitrogenous forms. They represent an intermediate form in de-nitrification and nitrification reactions in the nitrogen cycle. The major source of nitrites in the water body is biological decomposition. The estimated maximum amount of nitrites was $0.06 \mathrm{mg} / \mathrm{l}$ due to the possible inflow of nitrogen rich flood water into the lake. The lowest value was $0.02 \mathrm{mg} / \mathrm{l}$.

\section{Silicates:}

The importance of silicates in the production of algal growth is well recognized. The decreased amount of Silicates may occur when there is an abundance of diatoms. It has been considered as an important parameter regulating the diatomic population in fresh water eco systems. In the present investigation the value ranged 1.84 to $2.99 \mathrm{mg} / \mathrm{l}$.

\section{Organic matter:}

The organic debris and the substances which are biological in nature generate the oxidizable organic matter. The infusion of organic matter into ponds and lakes is in the form of external sources such as inflowing water from the areas outside the besin. The highest value of organic matter was found to be 1.6 $\mathrm{mg} / \mathrm{l}$ in September and lowest value was recorded of $0.6 \mathrm{mg} / \mathrm{l}$ in August.

\section{Chemical Oxygen Demand (COD):}

The estimation of COD along with BOD is helpful in indicating toxic conditions and the presence of non biodegradable substances in the water (Sawyer, McCarty \& Parkin, 2003). High amount of COD indicates presence of all forms of organic matter, both biodegradable and non biodegradable and degree of pollution of lake water. The estimated greater amount of COD was $28 \mathrm{mg} / \mathrm{l}$ in January and lowest was 14 $\mathrm{mg} / \mathrm{l}$ in May.

In the present investigation an attempt was made to generate base line information about some physicochemical characteristics and quality of peaddachearuvu lake water in different season. The 
winter, summer and monsoon seasons shows seasonal washing of cloths, fish culture and rituals. The water fluctuations in various physico-chemical parameters. parameters indicate that the lake is rich in nutrients. The water of present lake is utilized for irrigation,

\section{Station-I}

Table 1 - Monthly variation of Physico-chemical parameters of Peddacheruvu Lake water

\begin{tabular}{|c|c|c|c|c|c|c|c|c|c|c|c|c|c|}
\hline & $\begin{array}{l}\text { Oct- } \\
2018\end{array}$ & Nov & Dec & $\begin{array}{l}\text { Jan- } \\
2019\end{array}$ & Feb & Mar & Apr & May & June & July & Aug & $\begin{array}{c}\text { Sep- } \\
19\end{array}$ & Avg. \\
\hline Temp (in ${ }^{0} \mathrm{C}$ ) & 22.4 & 22.1 & 22.0 & 23.5 & 24.6 & 24.9 & 25.2 & 25.6 & 25.9 & 24.2 & 23.2 & 22.9 & 23.87 \\
\hline $\mathbf{p H}$ & 7.9 & 7.9 & 7.9 & 7.8 & 8.0 & 8.0 & 8.1 & 8.2 & 8.1 & 8.2 & 8.1 & 8.2 & 8.03 \\
\hline Carbonates & 41.24 & 46.26 & 26.24 & 51.61 & 31.24 & 46.31 & 36.21 & 51.92 & 25.56 & 39.34 & 48.42 & 42.64 & 40.58 \\
\hline Bicarbonates & 232.34 & 226.54 & 286.64 & 234.22 & 240.28 & 228.74 & 238.54 & 230.44 & 278.38 & 254.38 & 250.56 & 230.26 & 244.27 \\
\hline DO & 9.2 & 10.4 & 8.2 & 8.6 & 10.2 & 9.2 & 9.4 & 9.2 & 9.6 & 10.2 & 11.2 & 11.4 & 9.73 \\
\hline BOD & 10 & 8 & 10 & 8 & 6 & 8 & 10 & 8 & 8 & 4 & 4 & 4 & 7.33 \\
\hline TH & 170 & 184 & 208 & 202 & 240 & 178 & 186 & 194 & 168 & 172 & 132 & 184 & 184.83 \\
\hline Calcium & 40.12 & 51.28 & 53.58 & 48.86 & 36.24 & 44.28 & 44.96 & 46.92 & 41.24 & 42.66 & 42.28 & 44.64 & 44.75 \\
\hline Magnesium & 28.84 & 29.64 & 26.96 & 34.69 & 26.84 & 30.68 & 32.26 & 34.66 & 26.24 & 30.66 & 22.78 & 34.22 & 29.87 \\
\hline TDS & 340 & 330 & 320 & 320 & 360 & 400 & 410 & 380 & 320 & 340 & 310 & 360 & 349.16 \\
\hline Chlorides & 160.54 & 138.46 & 190.58 & 126.25 & 168.28 & 120.86 & 156.82 & 146.56 & 190.26 & 156.56 & 146.64 & 138.94 & 153.39 \\
\hline Sulphates & 28 & 26 & 36 & 32 & 36 & 30 & 34 & 30 & 34 & 32 & 36 & 24 & 31.5 \\
\hline Phosphates & 0.62 & 0.88 & 0.66 & 0.88 & 0.66 & 0.52 & 0.94 & 0.44 & 0.56 & 0.42 & 0.76 & 0.76 & 0.67 \\
\hline Nitrates & 0.66 & 0.74 & 0.94 & 0.86 & 0.84 & 0.64 & 0.66 & 0.98 & 1.12 & 1.08 & 0.98 & 0.96 & 0.87 \\
\hline Silicates & 1.86 & 2.46 & 1.54 & 2.24 & 2.44 & 2.14 & 1.76 & 2.74 & 2.98 & 1.64 & 1.78 & 2.14 & 2.14 \\
\hline $\begin{array}{c}\text { Organic } \\
\text { matter }\end{array}$ & 1.6 & 0.8 & 1.4 & 1.6 & 0.8 & 1.2 & 1.6 & 1.6 & 0.6 & 0.8 & 0.6 & 1.6 & 1.18 \\
\hline COD & 20 & 24 & 16 & 28 & 24 & 18 & 16 & 14 & 16 & 18 & 16 & 14 & 18.66 \\
\hline Nitrite & 0.04 & 0.02 & 0.04 & 0.04 & 0.06 & 0.05 & 0.05 & 0.04 & 0.04 & 0.06 & 0.02 & 0.04 & 0.04 \\
\hline
\end{tabular}


Monthly variation of Physico-chemical parameters of Peddacheruvu Lake water

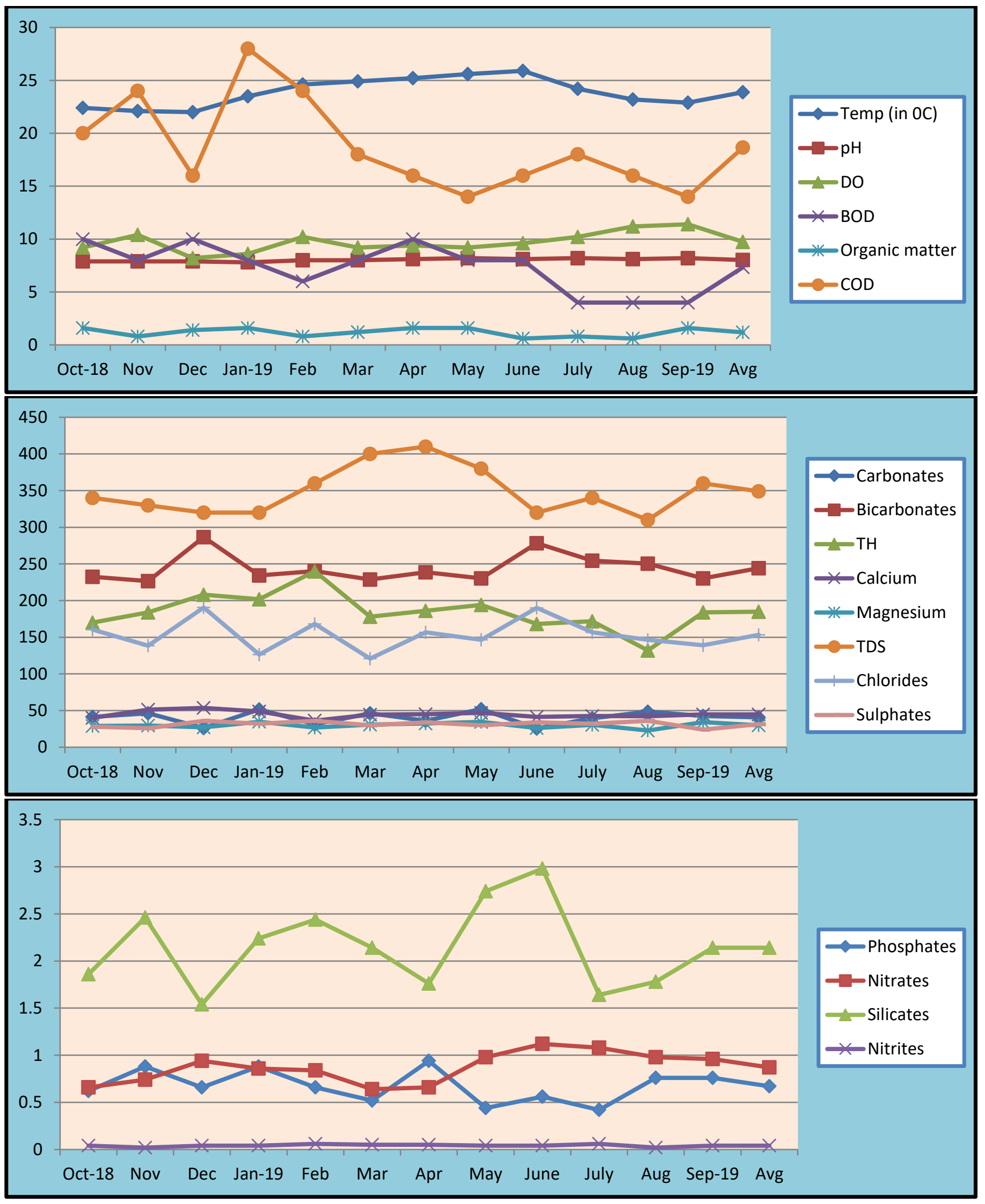


Station-II

Table 2-Monthly variation of Physico-chemical parameters of Peddacheruvu Lake water

\begin{tabular}{|c|c|c|c|c|c|c|c|c|c|c|c|c|c|}
\hline & $\begin{array}{l}\text { Oct- } \\
2018\end{array}$ & Nov & Dec & $\begin{array}{l}\text { Jan- } \\
2019\end{array}$ & Feb & Mar & Apr & May & June & July & Aug & Sep-19 & Avg. \\
\hline Temp(in $\left.{ }^{0} \mathrm{C}\right)$ & 22.4 & 22.1 & 22.0 & 23.5 & 24.6 & 24.9 & 25.2 & 25.6 & 25.9 & 24.2 & 23.2 & 22.9 & 23.87 \\
\hline pH & 7.9 & 7.8 & 7.8 & 7.8 & 7.9 & 8.0 & 8.0 & 8.1 & 8.2 & 8.1 & 8.2 & 8.2 & 8.0 \\
\hline Carbonates & 40.21 & 44.22 & 28.26 & 50.60 & 30.24 & 46.31 & 36.22 & 50.98 & 25.54 & 38.98 & 47.98 & 42.64 & 40.18 \\
\hline Bicarbonates & 232.34 & 225.98 & 286.64 & 234.20 & 239.28 & 228.74 & 238.56 & 231.44 & 277.96 & 254.38 & 250.58 & 231.98 & 244.34 \\
\hline DO & 9.8 & 10.2 & 8.2 & 8.4 & 9.8 & 9.2 & 9.2 & 9.4 & 9.2 & 10.4 & 11.4 & 11.2 & 9.7 \\
\hline BOD & 8 & 8 & 10 & 10 & 6 & 8 & 8 & 10 & 10 & 6 & 6 & 4 & 7.83 \\
\hline TH & 175 & 186 & 210 & 210 & 250 & 182 & 190 & 196 & 172 & 182 & 146 & 196 & 191.25 \\
\hline Calcium & 44.12 & 52.26 & 52.48 & 49.86 & 38.28 & 46.28 & 46.94 & 50.22 & 42.28 & 44.68 & 48.32 & 49.28 & 47.08 \\
\hline Magnesium & 29.86 & 28.66 & 28.98 & 36.88 & 30.82 & 32.66 & 34.36 & 38.64 & 28.28 & 36.22 & 28.76 & 38.66 & 38.73 \\
\hline TDS & 360 & 340 & 330 & 320 & 380 & 420 & 430 & 400 & 330 & 360 & 320 & 360 & 362.5 \\
\hline Chlorides & 162.52 & 140.44 & 180.56 & 130.25 & 170.28 & 140.86 & 158.82 & 148.56 & 196.28 & 160.52 & 148.66 & 142.92 & 150.72 \\
\hline Sulphates & 30 & 30 & 34 & 36 & 38 & 38 & 36 & 38 & 32 & 30 & 38 & 22 & 33.5 \\
\hline Phosphates & 0.68 & 0.78 & 0.86 & 0.68 & 0.60 & 0.56 & 0.98 & 0.58 & 0.56 & 0.38 & 0.66 & 0.68 & 0.66 \\
\hline Nitrates & 0.64 & 0.72 & 0.92 & 0.82 & 0.82 & 0.60 & 0.58 & 0.88 & 1.14 & 1.08 & 1.02 & 0.98 & 0.85 \\
\hline Silicates & 1.84 & 2.24 & 1.56 & 2.20 & 2.22 & 2.78 & 2.20 & 2.76 & 2.24 & 1.98 & 2.26 & 2.98 & 2.27 \\
\hline $\begin{array}{c}\text { Organic } \\
\text { matter }\end{array}$ & 1.5 & 0.8 & 1.3 & 1.5 & 0.8 & 1.2 & 1.5 & 1.6 & 0.6 & 0.9 & 0.6 & 1.6 & 1.18 \\
\hline COD & 20 & 22 & 24 & 18 & 24 & 18 & 18 & 16 & 18 & 20 & 20 & 18 & 19.66 \\
\hline Nitrites & 0.03 & 0.03 & 0.02 & 0.04 & 0.04 & 0.06 & 0.06 & 0.04 & 0.04 & 0.04 & 0.02 & 0.02 & 0.03 \\
\hline
\end{tabular}

\section{STATION-II}

Table 2-Monthly variation of Physico-chemical parameters of Peddacheruvu Lake water

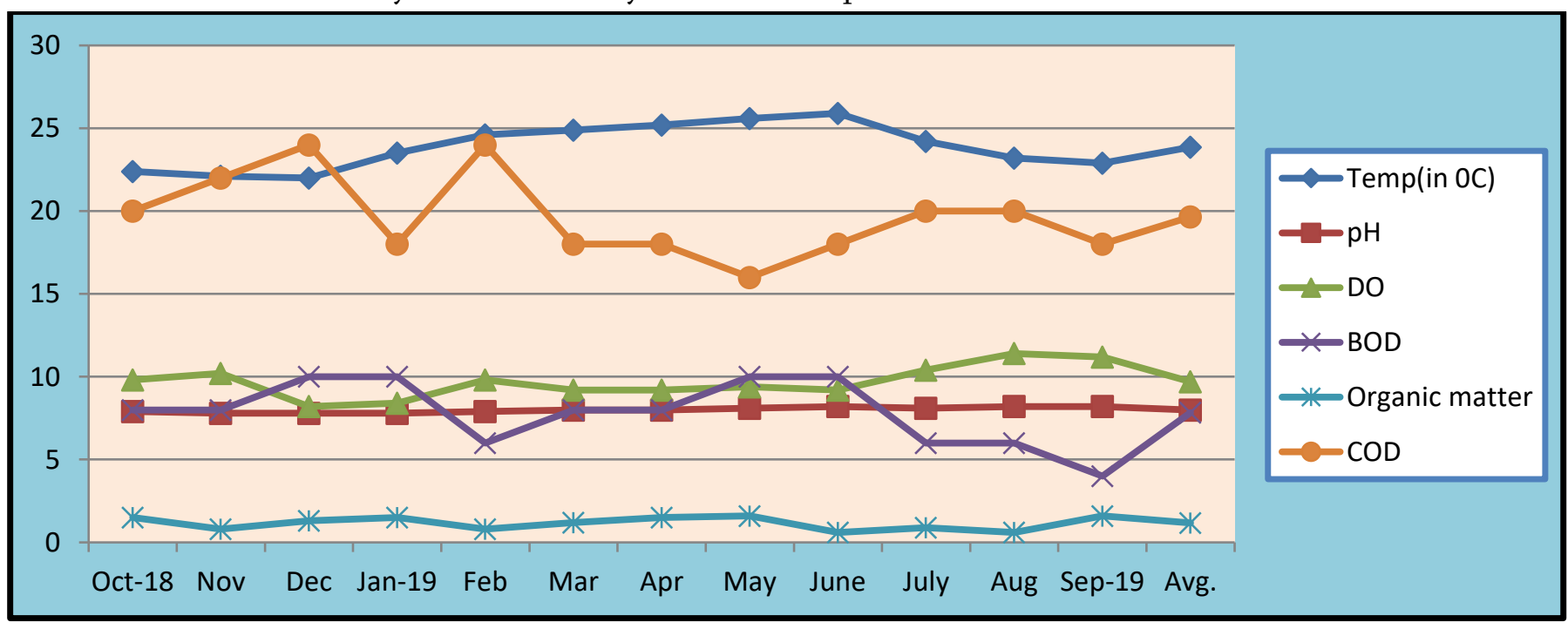




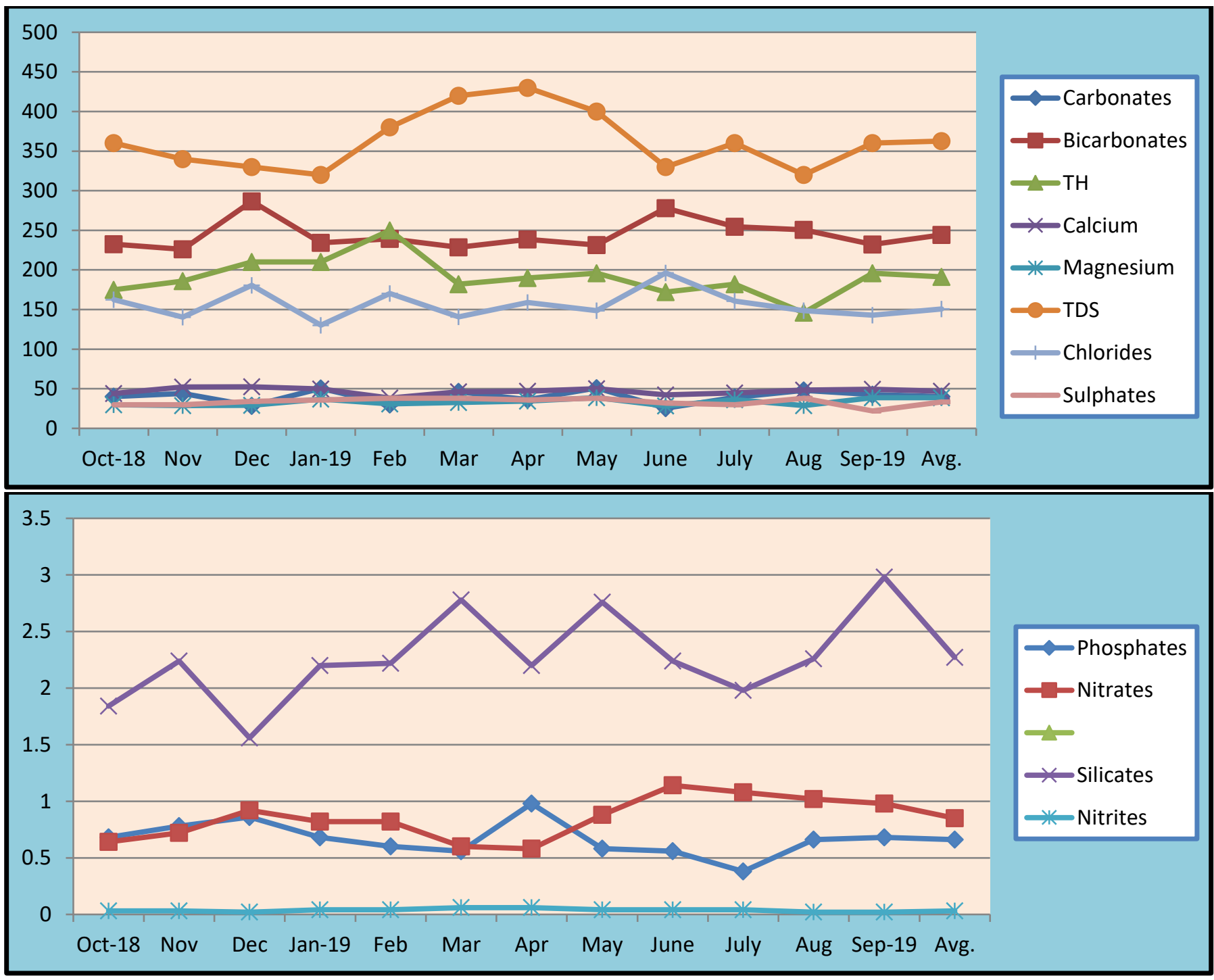

STATION-III

Table 1-Monthly variation of Physico-chemical parameters of Peddacheruvu Lake water

\begin{tabular}{|c|c|c|c|c|c|c|c|c|c|c|c|c|c|}
\hline & $\begin{array}{l}\text { Oct- } \\
2018\end{array}$ & Nov & Dec & $\begin{array}{l}\text { Jan- } \\
2019\end{array}$ & Feb & Mar & Apr & May & June & July & Aug & $\begin{array}{c}\text { Sep- } \\
19\end{array}$ & Avg \\
\hline Temp (in ${ }^{0} \mathrm{C}$ ) & 22.4 & 22.1 & 22.0 & 23.5 & 24.6 & 24.9 & 25.2 & 25.6 & 25.9 & 24.2 & 23.2 & 22.9 & 23.87 \\
\hline pH & 7.9 & 7.9 & 7.8 & 7.8 & 7.8 & 7.9 & 8.0 & 8.0 & 8.0 & 8.1 & 8.1 & 8.2 & 7.95 \\
\hline Carbonates & 41.20 & 43.20 & 30.28 & 48.66 & 32.44 & 48.32 & 40.28 & 52.22 & 28.36 & 38.22 & 48.96 & 48.98 & 41.76 \\
\hline Bicarbonates & 234.24 & 230.22 & 296.64 & 239.64 & 241.72 & 230.64 & 250.22 & 280.22 & 260.26 & 261.28 & 262.64 & 240.22 & 252.32 \\
\hline DO & 9.6 & 10.4 & 8.8 & 8.8 & 9.6 & 9.4 & 9.4 & 9.6 & 10.4 & 10.6 & 11.2 & 10.9 & 9.89 \\
\hline BOD & 10 & 8 & 8 & 10 & 10 & 8 & 6 & 8 & 10 & 10 & 8 & 6 & 8.5 \\
\hline TH & 178 & 199 & 220 & 225 & 260 & 192 & 198 & 202 & 194 & 192 & 156 & 220 & 203 \\
\hline Calcium & 45.16 & 53.22 & 53.96 & 51.88 & 40.22 & 44.66 & 47.88 & 51.24 & 44.38 & 43.98 & 49.28 & 50.22 & 48 \\
\hline Magnesium & 30.22 & 29.66 & 29.98 & 35.86 & 31.66 & 33.22 & 35.12 & 39.98 & 30.22 & 38.26 & 30.78 & 40.22 & 33.76 \\
\hline TDS & 380 & 360 & 340 & 325 & 375 & 420 & 435 & 410 & 340 & 380 & 310 & 365 & 370 \\
\hline Chlorides & 160.22 & 141.26 & 178.66 & 132.20 & 171.26 & 141.98 & 160.88 & 148.88 & 196.98 & 161.12 & 149.22 & 144.98 & 157.30 \\
\hline
\end{tabular}




\begin{tabular}{|c|c|c|c|c|c|c|c|c|c|c|c|c|c|}
\hline Sulphates & 32 & 34 & 34 & 36 & 32 & 32 & 38 & 38 & 36 & 34 & 30 & 28 & 33.66 \\
\hline Phosphates & 0.52 & 0.68 & 0.76 & 0.58 & 0.58 & 0.46 & 0.88 & 0.48 & 0.54 & 0.40 & 0.64 & 0.66 & 0.59 \\
\hline Nitrates & 0.64 & 0.70 & 0.88 & 0.86 & 0.84 & 0.66 & 0.62 & 0.78 & 1.02 & 1.08 & 1.04 & 1.02 & 0.84 \\
\hline Silicates & 1.99 & 2.50 & 2.02 & 2.99 & 2.66 & 2.98 & 2.40 & 2.88 & 2.24 & 2.02 & 2.28 & 2.98 & 2.49 \\
\hline $\begin{array}{c}\text { Organic } \\
\text { matter }\end{array}$ & 1.4 & 1.0 & 0.8 & 1.2 & 1.4 & 0.8 & 1.2 & 1.4 & 1.2 & 0.8 & 1.2 & 1.6 & 1.16 \\
\hline COD & 22 & 20 & 24 & 22 & 18 & 22 & 24 & 18 & 16 & 18 & 20 & 20 & 20.33 \\
\hline Nitrites & 0.02 & 0.02 & 0.04 & 0.03 & 0.04 & 0.02 & 0.02 & 0.04 & 0.06 & 0.04 & 0.02 & 0.04 & 0.03 \\
\hline
\end{tabular}

Monthly variation of Physico-chemical parameters of Peddacheruvu Lake water

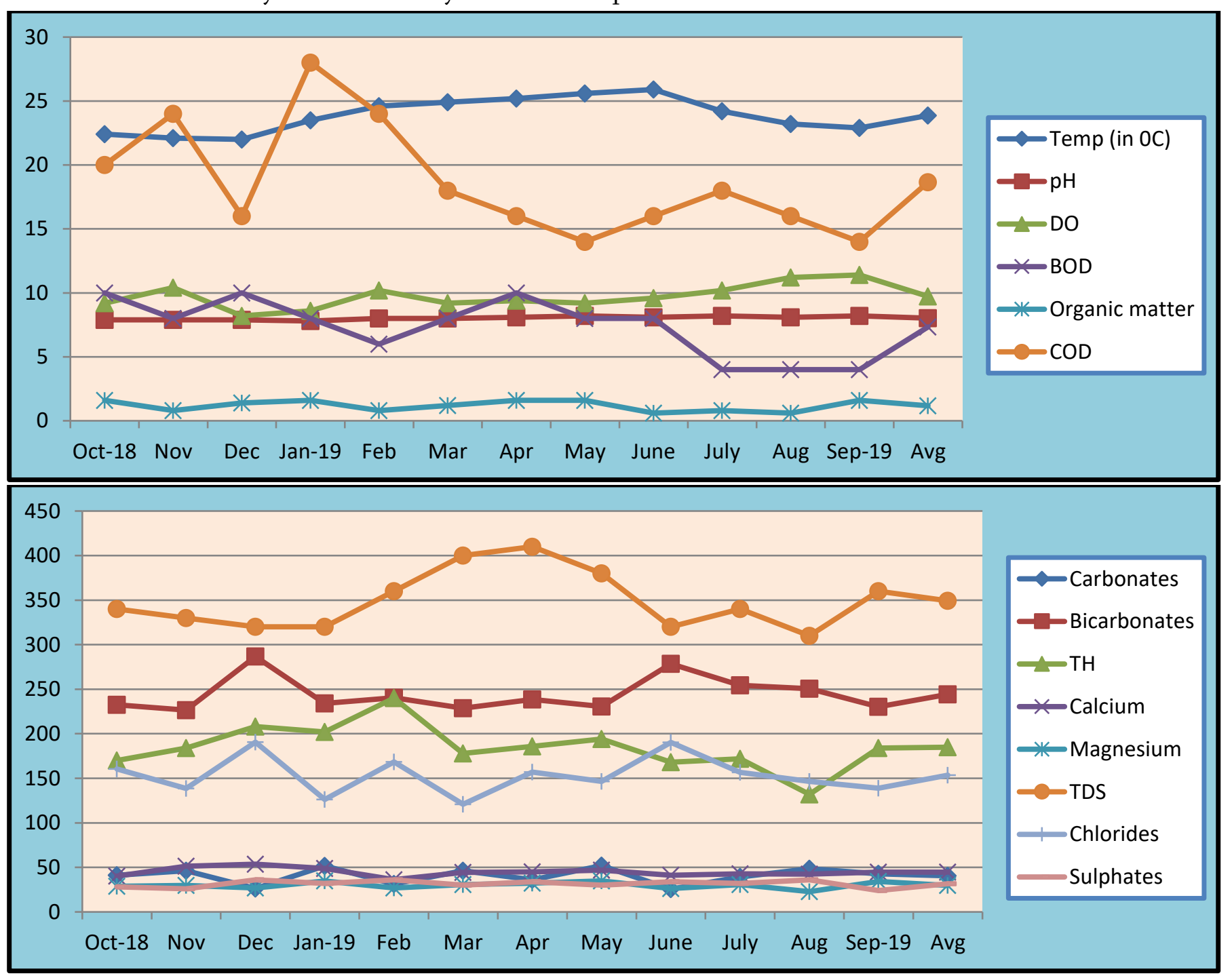




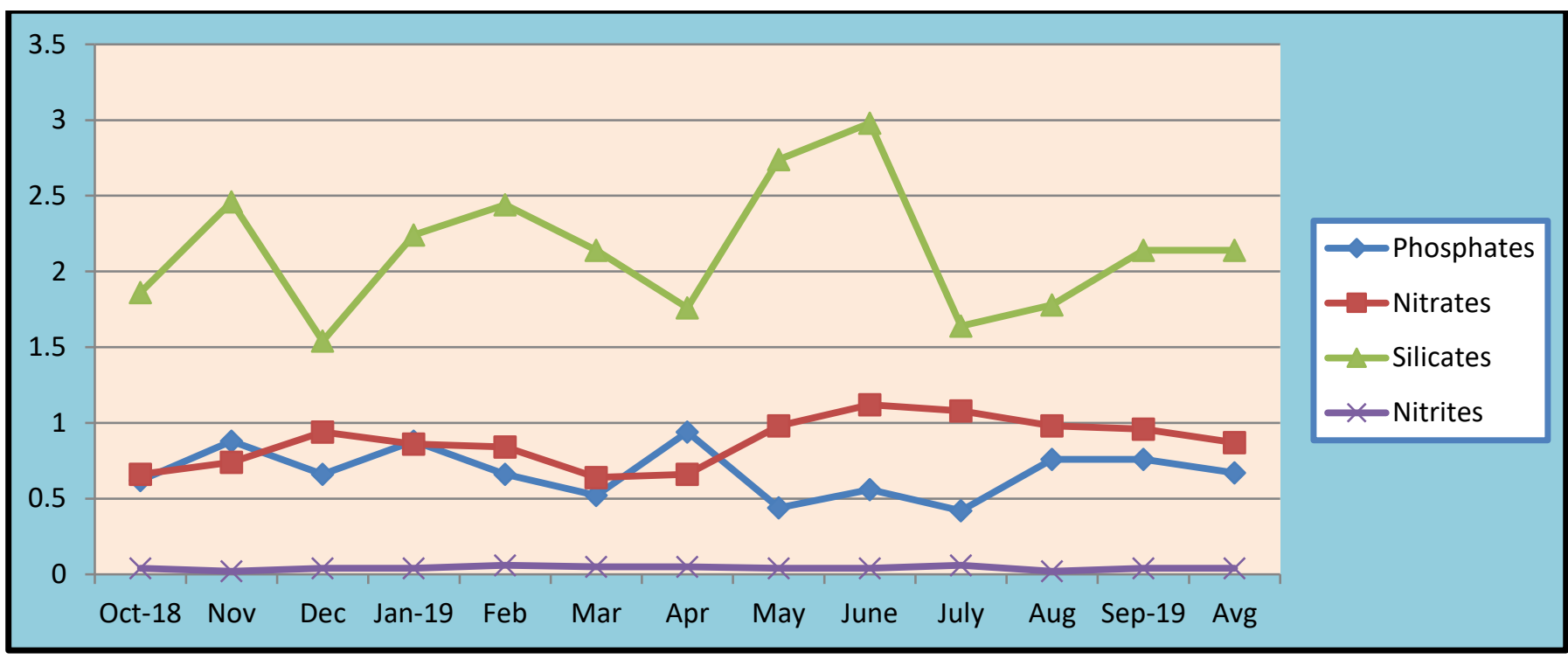

\section{IV.DISCUSSION AND CONCLUSION}

The Analysis of Physico-chemical parameters had indicated the wider human activity and influx of domestic waste into the lake caused to eutrification. The values of physico-chemical parameters assessed are found to be slightly above the permissible limit prescribed by WHO for drinking water. The physicochemical parameters show seasonal fluctuations. The water of present Peddacheruvu lake is useful for drinking, irrigation as well as fish culture.

\section{REFERENCES}

[1]. Ansari, K,K, Prakash.S.,(2000). Limnological studies on Tulasidas tal of tarai region of balrampur in relation to fisheries. Poll. Res. 19(4): 651-655.

[2]. APHA.,(2005). Standard Methods for the Examination of water and wastewater.21st ed. Washington D.C. U.S.A

[3]. Govindan.,V.S., \& Devika.,R., (1991). Limnological studies of heavy metal profiles of adyar river and wast stabilization pond. J. Ecotoxicol.Environ.Monit., 1(1): 53-58.
[4]. Hammer, M.J and Warren, V.J., (2005). Water Supply and Pollution Control.7th Edition. Pearson Prentice Hall. Upper Saddle River. 867pp.

[5]. Hegdae,B,A, Sureka,G, Ramadas, K, Yashovarma,B., (2005). Studies on the limnological characteristics of guruvayankara pond near Belthangady of Karnataka, India. Indian.J.Envir.and Ecoplanning. 10(1): 165-8.

[6]. Hutchison, G.E., (1957). A treatise on Limnology Vol.1.Geography, Physics and Chemistry. John Wiley and Sons Inc. New York. 1011pp.

[7]. Jhingran, V.G., (1991). Fish and Fisheries of India (3rd ed.), Hindustan Publishing Corporation (India) Delhi.

[8]. Naik T.P., K.V.Ajayan and G.H.Lokesh., (2012). Physico-chemical characteristics of Kunigal lake in Tumkur Dist., Karnataka, India.Int.J.Chem.Sci.10 (2):655-663.

[9]. Ramakrishna, Devikarani.,(2005). Environmental impact of chemical deicers. Water, air and soil pollution 166(1):49-63.

[10]. Ruth O.K., and M.E.C.Johnson., (2013). Water quality of Nadimi Lake, Hydrabad, AndhraPradesh, India.J.Aqua.Biol.27 (1):48-50. 
[11]. Salaskar, Pramod and Yeragi, S.G., (1997). Studies of water quality characteristic of Snehala lake, Kalyan, Maharashtra, India.J.Aqua.Biol.12 (1and 2):28-31.

[12]. Sawyer. C.N, McCarty, P.L., and Parkin, G,F.,(2002). Chemistry for environmental engineering science, 5ed. Newyork city: McGraw-Hill.

[13]. Srinivas, M., and Aruna, M., (2018). Physicochemical analysis of a lake, Erracheruvu in Siddipet, District of Telangana state, India. In. J. of.R.Sci. Research, Vol. 9, Issue.10 pp2942029425.

[14]. Stewart, K.M and Hasler, D. (1972). Limnology of some Madison lakes: Annual cycles. Wis. Acad.Sci.Arts Lett.60:87- 123.

[15]. Toma, J.J., (2000). Limnological study of Dokan Lake, Kurdistan region of Iraq. M.Sc. Thesis. University of Salahaddin. Arbil. Iraq.

[16]. Trivedi, R.K., and Goel,P.K.,(1986).Chemical and biological methods for water pollution studies, Environmental Publications, Karad, India.

\section{Cite this article as :}

D. Srinivas, Dr. K. Shailaja, "Limnological Studies of Pedda Cheruvu Lake in Rajgopalpet, Siddipet District, Telangana State ", International Journal of Scientific Research in Science and Technology (IJSRST), Online ISSN : 2395-602X, Print ISSN : 2395-6011, Volume 8 Issue 1, pp. 212-222, January-February 2021. Available at

doi : https://doi.org/10.32628/IJSRST218130

Journal URL : https://ijsrst.com/IJSRST218130 